\title{
Design of Structural Steelwork
}


Consulting Editor: Ray Hulse, Coventry University

Other titles of related interest:

Civil Engineering Construction - Design and Management D.R. Warren

Civil Engineering Contract Administration and Control, Second Edition I.H. Seeley

Civil Engineering Materials, Fourth Edition N. Jackson and R. Dhir (Editors)

Civil Engineering Quantities, Fifth Edition I.H. Seeley

Finite Elements - A Gentle Introduction David Henwood and Javier Bonet

Highway Traffic Analysis and Design, Third Edition R.J. Salter and N. Hounsell

Plastic Analysis of Steel and Concrete Structures, Second Edition S.J.J. Moy

Soil Mechanics - Principles and Practice G. Barnes

Reinforced Concrete Design, Fourth Edition W.H. Mosley and J.H. Bungey

Reinforced Concrete Design to Eurocode 2 W.H. Mosley, R.Hulse and J.H. Bungey

Structural Masonry, Second Edition Arnold W. Hendry

Structural Mechanics J. Cain and R. Hulse

Surveying for Engineers, Third Edition J. Uren and W.F. Price

Understanding Hydraulics L. Hamill

Understanding Structures, Second Edition Derek Seward 


\title{
Design of Structural Steelwork to BS 5950 and C-EC3
}

\author{
W.M.C. Mckenzie BSc, PhD, CPhys, MInstP, CEng \\ Lecturer, Napier University, Edinburgh
}

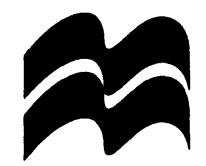


(C) W.M.C. McKenzie 1998

All rights reserved. No reproduction, copy or transmission of this publication may be made without written permission.

No paragraph of this publication may be reproduced, copied or transmitted save with written permission or in accordance with the provisions of the Copyright, Designs and Patents Act 1988, or under the terms of any licence permitting limited copying issued by the Copyright Licensing Agency, 90 Tottenham Court Road, London W1P 9HE.

Any person who does any unauthorised act in relation to this publication may be liable to criminal prosecution and civil claims for damages.

The author has asserted his right to be identified as the author of this work in accordance with the Copyright, Designs and Patents Act 1988.

First published 1998 by MACMILLAN PRESS LTD

Houndmills, Basingstoke, Hampshire RG21 6XS

and London

Companies and representatives throughout the world

ISBN 978-0-333-71579-6

ISBN 978-1-349-14612-3 (eBook)

DOI 10.1007/978-1-349-14612-3

A catalogue record for this book is available from the British Library.

This book is printed on paper suitable for recycling and made from fully managed and sustained forest sources.

$\begin{array}{llllllllll}10 & 9 & 8 & 7 & 6 & 5 & 4 & 3 & 2 & 1\end{array}$

$\begin{array}{llllllllll}07 & 06 & 05 & 04 & 03 & 02 & 01 & 00 & 99 & 98\end{array}$ 
To my parents Jeannie and Robert 


\section{Contents}

Preface

xii

Acknowledgements

xiii

1. Structural Steelwork 1

1.1 Introduction 1

1.2 The Design Process 5

1.2.1 Aims of Design 5

1.2.2 Structural Loading 6

1.2.3 Structural Analysis and Load Distribution 8

1.3 Example 1.1 Load distribution one-way spanning slabs $\quad 8$

1.4 Example 1.2 Two-way spanning slabs 9

1.5 Example 1.3 Secondary beams 11

1.6 Example 1.4 Combined one-way, two-way slabs and beams 12

1.7 Limit State Design BS 5950:Part 1: 1990

1.7.1 Ultimate Limit State 14

1.7.2 Serviceability Limit State 14

1.7.3 Partial Safety Factors 14

1.7.4 Application of Partial Safety Factors 14

1.8 Example 1.5 Brewery part floor plan load distribution $\quad 15$

$\begin{array}{lll}1.9 & \text { Application of Wind Loads } & 18\end{array}$

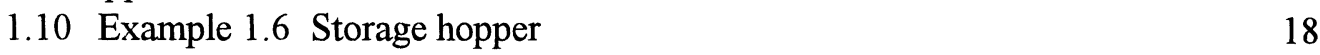

1.11 Example 1.7 Industrial warehouse $\quad 22$

1.12 Example 1.8 Radar reflector $\quad 32$

2. Flexural Members $\quad 34$

2.1 Introduction $\quad 34$

2.1.1 Plastic Sections $\quad 37$

2.1.2 Compact Sections $\quad 38$

2.1.3 Semi-Compact Sections $\quad 38$

2.1.4 Slender Sections $\quad 38$

2.2 Shear Capacity (Clause 4.2.3) 39

2.3 Example 2.1 Shear check of a simply supported beam 40

2.4 Moment Capacity (Clause 4.2.5) 41

2.4.1 Compression Flange Restraint 41

2.4.2 Effective Length $L_{e}$ (Clauses 4.3.5 and 4.3.6) 44

2.4.3 Moment Capacity $\left(M_{c}\right)$ of Beams with Full Lateral Restraint 46

2.5 Example 2.2 Bending in fully restrained beam 47

2.6 Moment Capacity $\left(\mathrm{M}_{\mathrm{b}}\right)$ of Beams without Full Lateral Restraint
(Clause 4.3.7)

2.6.1 Rigorous Method (Clause 4.3.7.1) 48

2.7 Example 2.3 Beam with intermittent lateral restraint 49 
2.8 Example 2.4 Beam with intermittent lateral restraint 53

2.9 Example 2.5 Rectangular hollow section as a beam 56

2.10 Example 2.6 Cantilever beam $\quad 57$

2.11 Web Buckling and Web Bearing 60

2.11.1 Web Buckling (Clause 4.5.2) 61

2.11.2 Web Bearing (Clause 4.5.3) 62

2.12 Example 2.7 Web bearing and web buckling at support 63

2.13 Deflection of Beams (Clause 2.5.1) 65

2.13.1 Equivalent UDL Technique 66

2.14 Example 2.8 Deflection of simply supported beam 68

2.15 Conservative Method for Lateral Torsional Buckling Moment Capacity (Clause 4.3.7.7) 70

2.16 Example 2.9 Simply supported beam 1 - conservative method 70

2.17 Example 2.10 Simply beam 2 - conservative method 71

2.18 Safe Load Tables $\quad 72$

2.19 Example 2.11 Beam with intermittent lateral restraint - Use of safe load tables

2.19.1 Shear $\quad 75$

2.19.2 Bending $\quad 75$

2.19.3 Web Buckling

2.19.4 Web Bearing 76

2.19.5 Deflection $\quad 76$

2.20 Example 2.12 Pedestrian walkway $\quad 77$

2.21 Solution to Example 2.2 78

2.22 Solution to Example 2.12 82

3. Axially Loaded Members $\quad 86$

$\begin{array}{lll}3.1 & \text { Introduction } & 86\end{array}$

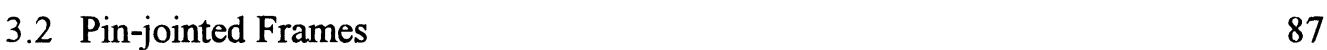

3.3 Résumé of Analysis Techniques 90

3.3.1 Method of Sections 90

3.4 Example 3.1 Pin-jointed truss 91

3.4.1 Joint Resolution 93

3.4.2 Tension Coefficients 96

3.5 Example 3.2 Two dimensional plane-truss 97

3.6 Example 3.3 Three dimensional space truss 98

3.7 Design of Tension Members (Clause 4.6) 99

3.8 Example 3.4 Lattice girder $\quad 105$

3.9 Design of Compression Members (Clause 4.7) 106

3.9.1 Slenderness (Clause 4.7.3) 107

3.9.2 Compressive Resistance (Clause 4.7.4) 109

3.10 Example 3.6 Secondary bracing in lattice girder 114

3.11 Example 3.7 Concentrically loaded single storey column 118

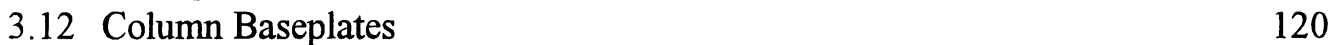

3.13 Example 3.7 Slab base 121 
4. Members Subject to Combined Axial and Flexural Loads 123

4.1 Introduction 123

4.1.1 Combined Tension and Bending 123

4.1.2 Reduced Moment Capacity 125

4.1.3 Combined Compression and Bending 127

$\begin{array}{ll}4.2 \text { Eccentricity of Loading } & 129\end{array}$

4.3 Section Classification 130

4.4 Example 4.1 Industrial unit 130

4.5 Columns in Simple Multi-Storey Construction (Clause 4.7.7) 135

4.6 Example 4.2 Multi-storey column in simple construction 136

4.7 Example 4.3 Lattice girder with secondary bending 141

5. Connections 145

5.1 Introduction 145

5.1.1 Simple Connections 146

5.1.2 Moment Connections 147

5.2 Bolted Connections 153

5.2.1 Black Bolts 153

5.2.2 High Strength Friction Grip Bolts (H.S.F.G.) 156

$\begin{array}{ll}\text { 5.2.3 Design of Simple Connections } & 158\end{array}$

5.3 Welded Connections $\quad 159$

5.3.1 Fillet Welds $\quad 160$

5.3.2 Butt Welds 161

5.3.3 Design of Fillet Weld Connections 162

5.4 Beam End Connections 164

5.4.1 Double-Angle Web Cleats 164

5.4.2 Flexible End Plates $\quad 165$

5.4.3 Fin Plates 165

5.5 Example 5.5 Web cleat, end plate and fin plate connections 166

$\begin{array}{ll}5.6 \text { Design of Moment Connections } & 167\end{array}$

5.6.1 Typical Site Connection Using H.S.F.G. Bolts 168

5.6.2 Example 5.6 Moment connection in rectangular portal frame 168

5.6.3 Example 5.7 Crane bracket moment connection 170

$\begin{array}{lll}5.7 \text { Splices } & 171\end{array}$

$\begin{array}{lll}5.7 .1 & \text { Beam Splices } & 171\end{array}$

5.7.2 Example 5.8 Beam splice 172

$\begin{array}{ll}5.7 .3 \text { Column Splices } & 178\end{array}$

5.7.4 Example 5.9 Column splice 180

5.8 Solution to Example 5.1 183

5.9 Solution to Example 5.2 185

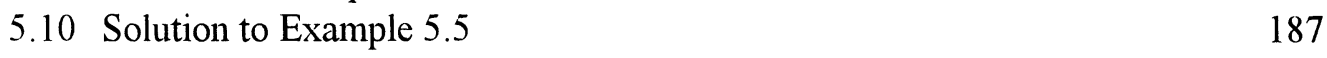

5.11 Solution to Example 5.6 196 
6. Plate Girders 198

6.1 Introduction 198

6.1.1 Design Load Effects 200

6.2 Initial Sizing 201

6.3 Moment and Shear Capacity 201

6.4 Deflection 203

6.5 Intermediate Stiffeners 203

6.6 Load Bearing Stiffeners 203

6.7 Example 6.1 Plate girder in multi-storey office block 203

6.7.1 Design Loading 205

6.7.2 Column Loads 205

6.7.3 Initial Sizing 206

6.7.4 Section Classification (Clause 3.5) 207

$\begin{array}{ll}6.7 .5 & \text { Flanges } \\ 6.7 .6 & 207\end{array}$

6.7.6 Web 208

6.7.7 Moment Capacity (Clause 4.4.4.2(a)) 209

$\begin{array}{ll}\text { 6.7.8 Shear Capacity (Clause 4.4.5.3) } & 209\end{array}$

6.7.9 Deflection (Clause 2.5) 210

6.7.10 Intermediate Stiffeners (Clause 4.4.6) 212

6.7.11 Load Bearing Stiffeners (Clause 4.5) 213

6.7.12 Flange to Web Connection 217

6.8 Example 6.2 Plate girder with intermittent restraint to flange 218

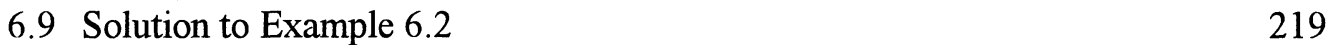

7. Concise Eurocode 3 C-EC3 230

$\begin{array}{ll}7.1 \text { Introduction } & 230\end{array}$

7.1.1 National Application Document (NAD) 230

7.1.2 Concise EC3 (C-EC 3) 230

7.2 Terminology, Symbols and Conventions 231

7.2.1 Decimal Point 231

7.2.2 Actions 231

7.2.3 Resistance 232

$\begin{array}{ll}7.2 .4 \text { Subscripts } & 232\end{array}$

$\begin{array}{ll}7.2 .5 & \text { Design Values } \\ 7.26 & 232\end{array}$

7.2.6 Partial Safety Factors $\quad 232$

7.2.7 Symbols 233

7.2.8 Conventions 234

7.2.9 Materials 235

7.3 Section Classification 236

7.4 Use of C-EC 3

7.4.1 Example 7.1 Beam with full lateral restraint 236

7.5 Lateral Torsional Buckling (LTB) (Clause 5.5.5) 246

7.6 Example 7.2 Beam with intermediate and end restraints 247

7.7 Example 7.3 Truss members with axial tension/compression 251

7.8 Example 7.4 Concentrically loaded single storey column 256 
7.9 Axially Loaded Members with Moments

7.10 Example 7.5 Multi-storey column in simple construction 


\section{Preface}

Most engineers/engineering technicians develop their initial understanding of structural design by undertaking a recognised, structured undergraduate course of study. The material covered in such courses requires the student to refer to and use relevant British Standard Codes of Practice. Many practising engineers/technicians do not become involved in design immediately following graduation and require reference material with which to update and refresh their knowledge of design.

This text has been prepared for both types of reader. It is suitable for students undertaking degree or diploma level studies in architecture, civil, structural or building engineering.

The aim of the text is to develop an understanding of Limit State Design as applied to structural steelwork. It is assumed that readers will have access to and use the relevant British Standard Codes of Practice, i.e. BS 5950:Part 1, BS 6399:Parts 1 and 2 and the Concise Eurocode C-EC3.

The British Standards Institution publishes a selection of extracts from various codes entitled Extracts from British Standards for students of structural design; students using this document will be undertaking a course of study which is less extensive than the range covered by the present text and they may choose to ignore the additional more detailed material and clause references that it includes.

The use of the codes, particularly BS 5950:Part 1 is explained and demonstrated in numerous worked example and illustrations. The text is both extensive and comprehensive; it includes explanations of structural analysis and load distribution techniques where considered appropriate. Student readers are strongly advised to read, use and familiarise themselves with the terminology adopted in design codes by frequent references to relevant clauses throughout the text. Structural design cannot be efficiently carried out without reference to design codes.

The complexity and nature of modern design codes necessitates reference to additional material for full explanations of the rationale behind their development; appropriate sources are provided in the bibliography.

A selection of design examples from Chapters 2, 5 and 6 are presented in a format typical of that used in a design office in order to encourage students to adopt a methodical and rational approach in preparing structural calculations. The solutions for these examples are given at the end of their respective chapters.

W.M.C. MKenzie 


\section{Acknowledgements}

The author and the publishers are grateful to the following organisations for permission to reproduce copyright material in this book.

Extracts from BS 5950: Part 1: 1990 are reproduced with the permission of BSI. Complete editions of the standards can be obtained by post from BSI Customer Services, 389 Chiswick High Road, London W4 4AL.

Extracts of tables from

Steelwork design guide to BS 5950: Part 1: Volume 1

$C-E C 3$ - Concise Eurocode for the design of steel buildings in the United Kingdom have been reproduced by kind permission of the Director, The Steel Construction Institute. Complete copies can be obtained from The Steel Construction Institute, Silwood Park, Ascot, Berks SL5 7QN. 